\title{
PREDATORY PERFORMANCE OF COCCINELLA TRANSVERSALIS AND ITS MOLECULAR IDENTIFICATION
}

\author{
Susmita Sarker, Abdul Jabber Howlader, Faria Farhana Rain, \\ Abu Faiz Md. Aslam* \\ Department of Zoology, Jahangirnagar University, Savar, \\ Dhaka-1342, Bangladesh
}

\begin{abstract}
Predatory efficacy of Coccinella transversalis (Coleoptera: Coccinellidae) on three detrimental agriculturally important aphids (Aphis craccivora, A. fabae and $A$. gossypii) was studied under laboratory condition. The $4^{\text {th }}$ instar larvae of $C$. transversalis consumed highest $(21.56 \pm 1.72)$ number of $A$. craccivora aphids followed by $A$. fabae $(12.33 \pm 1.74)$ and $A$. gossypii $(13.99 \pm 0.77)$. Life cycle studies of $C$. transversalis on the above three aphid species revealed that it took maximum $(27.66 \pm 3.06)$ days to complete life cycle while reared on A. craccivora followed by $A$. fabae $(25.66 \pm 0.58$ days $)$ and $A$. gossypii $(22.33 \pm 1.52$ days $)$ respectively. As C. transversalis is a potential predator, an attempt was taken to identify this biological control agent based on mitochondrial cytochrome c oxidase (COI) gene sequence. Sequenced gene was submitted to the NCBI GenBank database (Accession NO. MG 587947.1) followed by proper procedure. Phylogenetic relationship of the beetle was constructed based on mitochondrial COI gene. The nucleotide composition analysis revealed that the value of $\mathrm{A}+\mathrm{T}$ $(69.3 \%)$ was greater than $\mathrm{G}+\mathrm{C}(30.7 \%)$. Such study of $C$. transversalis would be helpful in biological control programme of aphid pest.
\end{abstract}

Key words: Coccinella transversalis, Predatory efficacy, DNA barcode

\section{INTRODUCTION}

Damage in agricultural and horticultural crops caused by aphids is very dreaded problem because one aphid is enough to profound damage for large crop area by transmitting the viral diseases (Difonzo et al. 1997, Raboudi et al. 2002). It is especially harmful in nurseries and young orchards (Dean and Sterling 1992). It has been reported that this pest accounts for yield losses ranging from 37 to 90\% (Abate et al. 2000, Ampofo and Massomo 2009). The use of insecticides for controlling this pest causes several adverse side-effects (Ahmed and Akhtar 2013). These adverse effects of synthetic insecticides can be overcome by the use of biological control agents (Bellows 2001).

*Author for correspondence: <afm.aslam@gmail.com>.

@2019 Zoological Society of Bangladesh DOI: https://doi.org/10.3329/bjz.v47i2.44334 
The coccinellid predators are tolerant to many insecticides which is an advantage over other predators (Banks and Stark 2011). Both the adult and larval stages of the coccinellid beetle, Coccinella transversalis feeds primarily on diverse aphids (Karpacheva 1991, Nunez-Perez et al. 1992). But there is lack of data on choice to consume aphid species by this predator. Improved understanding of coccinellid activity and predation on aphids in the laboratory could clarify their potential in aphid biological control. The present studies were conducted to determine the biology of Coccinella transversalis and its predatory efficacy on three detrimental aphid species of agricultural crops, i.e. A. craccivora, A. fabae and A. gossypii (Hossain et al. 2006. Aslam and Bashar 2001, Chowdhury et al. 2008) under laboratory conditions.

Considering their economic importance, timely and accurate identification of coccinellid predator species is crucial for effective pest management strategies. The taxonomic study revealed that, there exist huge morphological variations within the species that lead huge dilemma to identify insects accurately (Ball and Armstrong 2006, Singh and Singh 2014). Unlike other insect species, limited molecular studies have been undertaken in the members of the subfamily Coccinellidae of the insect order Coleoptera (Lyla and Haseena 2008). A novel methodology known as DNA barcoding has the potential to mitigate the challenges posed by identification of insect pests (Rugman-Jones et al. 2009, Gariepy et al. 2007, Guicke et al. 2012, Sethusa et al. 2014). DNA barcoding involves the PCR amplification and sequencing of a key genetic marker from a given specimen (Gariepy et al. 2007). A short, standardized region of its genome, specifically the mitochondrial gene, cytochrome c oxidase subunit 1 (COI) is used in most of the cases (Hebert et al. 2004).

Therefore, an initiative was undertaken for the molecular identification and characterization of $C$. transversalis based on $C O I$ gene sequences and the sequences will be submitted to the NCBI GenBank. The overall goal is to avail tools that will contribute to timely and accurate identification of these biological control agents, which should in turn facilitate quicker and effective implementation of pest management and strengthening of the IPM systems in countries affected by the aphid species.

\section{MATERIAL AND METHODS}

Assessment of predatory efficacy: The predatory efficacy of larval stages of Coccinella transversalis were tested on three agriculturally important aphid species i.e. Aphis craccivora, A. fabae and A. gossypii separately under controlled

conditions $\left(26 \pm 2{ }^{\circ} \mathrm{C}\right.$ and $\left.65 \pm 5 \% \mathrm{RH}\right)$. To maintain a regular supply of the aphid and beetle population, a garden of bean, Lablab purpureus and brinjal plants, 
Solanum melongena were maintained at the Insect Rearing and Experimental Station, Department of Zoology, Jahangirnagar University.

To investigate the predatory efficacy of larvae of the predator against aphids, newly hatched larvae of the predator were placed singly in six Petri dishes having a Whatman filter paper. A counted number of aphids (30) were provided in each Petri dish daily. Upper collar portion of the Petri dishes was treated with vaseline and covered with muslin cloth to avoid larval escape. Everyday, old leaves were substituted with new ones and unconsumed numbers of aphids were noted. The predation potential of larvae of the predator was investigated by feeding the grubs on aphids. The number of aphids consumed per day, during the period of study was recorded in each treatment by counting the number of remaining aphids and subtracting them from the total number of aphids provided. The larvae of the predator were also checked daily for their moulting to calculate the duration of each larval instar. This practice was continued until pupation.

\section{Molecular identification}

DNA isolation: Coccinella transversalis was collected from the stock culture of Molecular Entomology Laboratory of Jahangirnagar University. The genomic DNA was extracted from somatic tissue rich in mitochondria, e.g., leg or elytra (Levenbook and Williams 1956) using Wizard ${ }^{\circledR}$ Genomic DNA Purification Kit, USA, following the manufacturer's protocol with slight modification as mentioned in Aslam et al. 2019. The remaining parts of insects and respective individuals were kept as voucher specimens. Processed DNA was stored at $4^{\circ} \mathrm{C}$ or $-20^{\circ} \mathrm{C}$.

DNA quantification and quality measurement: The quantity and purity of DNA was measured by using Nano drop ${ }^{\mathrm{TM}} 2000$ spectrophotometer (Thermo Fisher Scientific, USA). $1 \mu \mathrm{l}$ of nucleic acid was used to quantify nucleic acid. 260/280 Ratio, the ratio of absorbance was used to assess the purity of DNA. A ratio of $\sim 1.8$ was generally accepted as "pure" for DNA.

Polymerase chain reaction (PCR): The extracted DNA was subjected to PCR amplification through Applied Biosystems ${ }^{\circledR}$ Veriti ${ }^{\circledR}$ 96-Well Thermal Cycler following standard protocols. Primers used were forward primer: (LCO 1490 5'GGTCAACAAATCATAAAGATATTG G-3') and reverse primer: (HCO 2198 5'TAAACTTCAGGGTGACCAAAAAATCA-3'). The PromegaGotaq ${ }^{\circledR}$ G2 Green Master Mix (Promega Corporation) was used that contained GoTaq ${ }^{\circledR}$ G2 DNA polymerase, dNTPs, $\mathrm{MgCl}_{2}$ and reaction buffers at optimal concentrations for efficient amplification of a wide range of DNA templates by PCR. The PCR reaction mixture consisted of total volume $20 \mu \mathrm{l}$ among that master mix - $10 \mu \mathrm{l}$, 
forward primer - $1 \mu \mathrm{l}$ (10 picomolar), reverse primer - $1 \mu \mathrm{l}$ (10 picomolar), template DNA (50 mg), and adjustable nuclease free water. Thermocycling consisted of an initial denaturation of $94^{\circ} \mathrm{C}$ for $3 \mathrm{~min}$, followed by 30 cycles of denaturation at $94^{\circ} \mathrm{C}$ for $30 \mathrm{sec}$, annealing at $49^{\circ} \mathrm{C}$ for $30 \mathrm{sec}$, extension at $72^{\circ} \mathrm{C}$ for $1 \mathrm{~min}$, final extension: $72^{\circ} \mathrm{C}$ for $10 \mathrm{~min}$ and hold: $4^{\circ} \mathrm{C}$.

Gel electrophoresis: The PCR amplified product was separated by $1 \%$ agarose gel electrophoresis (in 1XTAE buffer). The DNA of PCR products was visualized by using UV-Transilluminator under gel documentation system - BioDoc Analyzer of Biometra, UK.

COI gene sequencing: The PCR products were purified using Promega Wizard $^{\circledR}$ SV Gel \& PCR clean up system manufactured by Promega Corporation, USA following manufacturer's protocol. The quantity and purity of PCR purified products was checked by spectrophotometer. DNA sequencing was performed to determine the nucleotide sequence in cytochrome oxidase I region. BigDye ${ }^{\circledR}$ Terminator v3.1 cycle sequencing kit was used in this process. Each species was bi-directionally sequenced to get sequence of both (5' and 3') the DNA strands.

Submission of gene to GenBank: BioEdit v.7.0.5 software was used for checking the quality of sequenced data. Homology, insertions - deletions, stop codons, and framshifts was checked using NCBI BLAST. BankIt, a WWW-based submission tool with wizards to guide the submission process was used. The GenBank database was designed for new sequence data that was determined and annotated by the submitter. Sequence was uploaded to GenBank.

Data analysis: The chromatograms were converted to FASTA format using FinchTV chromatogram viewer software. The DNA sequences in ABI file were manually edited using BioEdit v.7.0.5. Results of sequence editing were analyzed using BLAST (Basic Local Alignment Search Tool) NCBI to indicate the homology from closest species. Phylogenetic tree was constructed using maximum likelihood method, calculation using Bootstrap with 1000 times of repetition in MEGA (Molecular Evolutionary Genetic Analysis) software program v.10.0. (Tamura et al. 2013). COI gene sequence of five coccinellid beetle (Coccinella transversalis) was also collected from National Centre for Biotechnology Information (NCBI) to compare with the research sample for their phylogenetic analysis.

\section{RESULTS AND DISCUSSION}

Predatory efficacy: The results of the tests of predatory efficacy of the larval stages of Coccinella transversalis on three aphid species, viz. Aphis craccivora, A. fabae and $A$. gossypii are presented in Table 1. The1st and 2nd instar larvae were found to consume maximum number of $A$. fabae aphids $(5.67 \pm 0.58$ and 
$8.33 \pm 0.58)$. In comparison, $3^{\text {rd }}$ and $4^{\text {th }}$ instar larvae predate highest $(13.66 \pm$ 0.85 and $21.56 \pm 1.72$ ) number of $A$. craccivora aphids followed by $A$. fabae $(10.17 \pm 1.65,12.33 \pm 1.74)$ and $A$. gossypii $(12.17 \pm 1.34,13.99 \pm 0.77)$ respectively. According to Gurung et al. (2018), the total number of aphids,

Table1. Predatory efficacy of the coccinellid beetle, Coccinella transversalis larval stages on three different aphid species

\begin{tabular}{|c|c|c|c|c|c|}
\hline Attributes & & & Max. & Min. & Predatory efficacy \\
\hline \multirow[t]{12}{*}{ Larva } & \multirow[t]{3}{*}{ 1st instar } & A. craccivora & 5 & 4 & $4.67 \pm 0.57$ \\
\hline & & A. fabae & 6 & 5 & $5.67 \pm 0.58$ \\
\hline & & A. gossypii & 6 & 4 & $4.67 \pm 1.15$ \\
\hline & \multirow[t]{3}{*}{ 2nd " } & A. craccivora & 11 & 9 & $5.67 \pm 0.58$ \\
\hline & & A. fabae & 9 & 8 & $8.33 \pm 0.58$ \\
\hline & & A. gossypii & 8 & 7 & $7.33 \pm 0.58$ \\
\hline & \multirow[t]{3}{*}{ 3rd " } & A. craccivora & 17 & 11 & $13.66 \pm 0.85$ \\
\hline & & A. fabae & 11 & 9 & $10.17 \pm 1.65$ \\
\hline & & A. gossypii & 14 & 11 & $12.17 \pm 1.34$ \\
\hline & \multirow[t]{3}{*}{4 th " } & A. craccivora & 29 & 15 & $21.56 \pm 1.72$ \\
\hline & & A. fabae & 15 & 10 & $12.33 \pm 1.74$ \\
\hline & & A. gossypii & 16 & 11 & $13.99 \pm 0.77$ \\
\hline
\end{tabular}
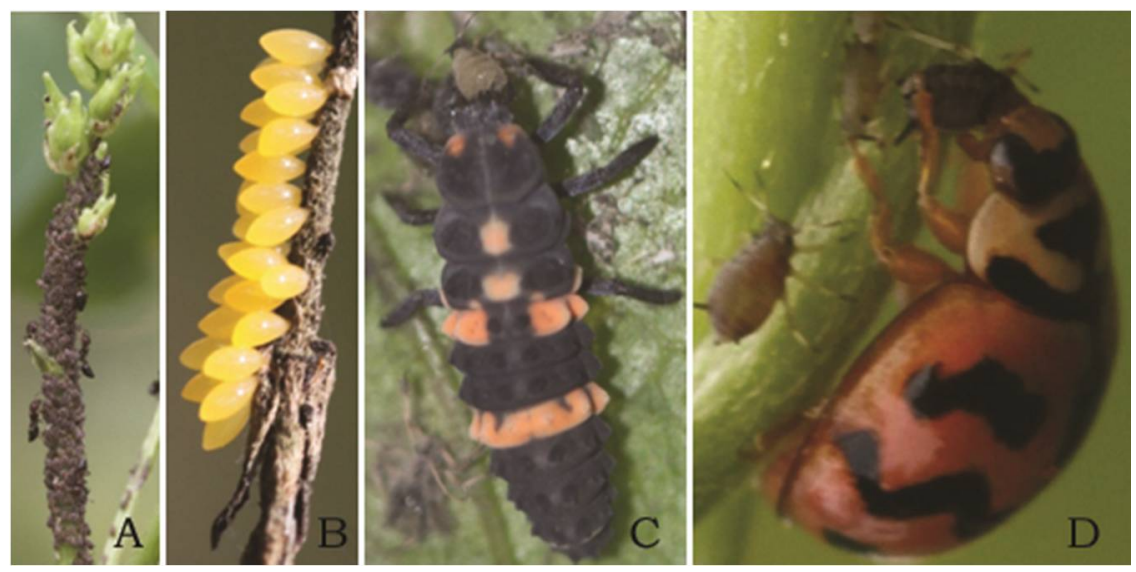

Fig. 1. A. An infested shoot, B. Eggs of C. transversalis, C. 4th instar larva predating on aphid, D. Aphid predation by adult of $C$. transversalis.

consumed by each instar grub, viz. first, second, third, fourth were $15.4 \pm 4.39$, $27.2 \pm 5.40,37.15 \pm 5.27,44.3 \pm 7.60$ aphids per grub per day. On the other hand, Chakraborty and Korat 2014 also reported that the feeding potential of 1st, 2nd ,3rd and 4th instar grub of as C. transversalis $22.33 \pm 0.89,37.20 \pm$ $1.22,47.93 \pm 1.41,66.47 \pm 2.28$ aphids, respectively when reared on $L$. erysimi. 
Life cycle: Life cycle of $C$. transversalis was observed on three detrimental aphid pests, viz. A. craccivora, A. fabae, A. gossypii separately under controlled temperature $\left(26 \pm 2{ }^{\circ} \mathrm{C}\right)$ and relative humidity $(65 \pm 5 \%)$ in laboratory condition (Table 2). The incubation period varied from 2 to 5 days with an average $2.70 \pm$ 0.766 days and the hatching percentage of eggs was also remarkable (83.33 \pm 14.57). It shows similarity with Shukla and Jadhav (2014). The duration of fourth instar larvae of $C$. transversalis varied with an average $3.00 \pm 0.0,3.66 \pm$ 0.58 and $4.66 \pm 0.58$ days when reared on A. craccivora, A. fabae and A. gossypii,

Table 2. Life cycle of $C$. transversalis reared on $A$. craccivora, $A$. fabae and $A$. gossypii

\begin{tabular}{|c|c|c|c|c|c|}
\hline Attributes & & & Max. & Min. & Mean $\pm \mathrm{Sd}$ \\
\hline Incubation period (days) & & & 5 & 2 & $2.70 \pm 0.77$ \\
\hline Hatching percentage & & & 95 & 67 & $83.33 \pm 14.57$ \\
\hline \multicolumn{6}{|l|}{ Larva (days) } \\
\hline & $1^{\text {st }}$ instar & A. craccivora & 4 & 2 & $2.66 \pm 1.15$ \\
\hline & & A. fabae & 2 & 2 & $2 \pm 0$ \\
\hline & & A. gossypii & 3 & 2 & $2.66 \pm 0.58$ \\
\hline & $2^{\text {nd }}$ instar & A. craccivora & 3 & 2 & $2.33 \pm 0.58$ \\
\hline & & A. fabae & 3 & 2 & $2.66 \pm 0.58$ \\
\hline & & A. gossypii & 3 & 3 & $3 \pm 0$ \\
\hline & $3^{\text {rd }}$ instar & A. craccivora & 4 & 3 & $3.33 \pm 0.58$ \\
\hline & & A. fabae & 3 & 3 & $3 \pm 0$ \\
\hline & & A. gossypii & 4 & 3 & $3.66 \pm 0.58$ \\
\hline & $4^{\text {th }}$ instar & A. craccivora & 3 & 3 & $3 \pm 0$ \\
\hline & & A. fabae & 4 & 3 & $3.66 \pm 0.58$ \\
\hline & & A. gossypii & 5 & 4 & $4.66 \pm 0.58$ \\
\hline \multicolumn{6}{|l|}{$\begin{array}{l}\text { Total larval development } \\
\text { period (days) }\end{array}$} \\
\hline & & A. craccivora & 12 & 11 & $11.33 \pm 0.58$ \\
\hline & & A. fabae & 13 & 12 & $12.33 \pm 0.58$ \\
\hline & & A. gossypii & 13 & 11 & $12.33 \pm 1.15$ \\
\hline \multirow[t]{3}{*}{ Prepupal period (days) } & & A. craccivora & 1 & 1 & $1 \pm 0$ \\
\hline & & A. fabae & 1 & 1 & $1 \pm 0$ \\
\hline & & A. gossypii & 1 & 1 & $1 \pm 0$ \\
\hline \multirow[t]{3}{*}{ Pupal period (days) } & & A. craccivora & 3 & 2 & $2.33 \pm 0.58$ \\
\hline & & A. fabae & 3 & 2 & $2.66 \pm 0.58$ \\
\hline & & A. gossypii & 3 & 3 & $3 \pm 0$ \\
\hline \multirow[t]{3}{*}{ Total life cycle (days) } & & A. craccivora & 31 & 25 & $27.66 \pm 3.06$ \\
\hline & & A. fabae & 26 & 25 & $25.66 \pm 0.58$ \\
\hline & & A. gossypii & 24 & 21 & $22.33 \pm 1.52$ \\
\hline
\end{tabular}


respectively. On the other hand, Shukla and Jadhav (2014) observed the duration of fourth instar larvae of $C$. transversalis varied with an average $4.14 \pm$ $0.888,3.74 \pm 0.823$ and $4.36 \pm 1.084$ days when reared on A. craccivora, $L$. erysimi and $M$. persicae. However, Solangi et al. (2007) recorded that fourth instar larvae of $C$. undecimpunctata lasted for $3.3 \pm 0.94$ days when reared on mustard aphid, L. erysimi. Khursheed et al. (2006) found that the mean duration of fourth instar larvae of $C$. septempunctata was $4.0 \pm 0.58$ days when reared on $L$. erysimi while it was 2.1 days in case of $H$. convergence when fed $L$. erysimi (Lohar et al. 2012).

The total life cycle of $C$. transversalis varied from 25 - 31, 25 - 26 and 21 - 24 days when reared on A. craccivora, A. fabae and A. gossypii with an average $27.66 \pm 3.06,25.66 \pm 0.58$ and $22.33 \pm 1.52$ days, respectively in laboratory condition.

\section{Molecular characterization}

Sequence result and BLAST analysis: The PCR results were separated using $1 \%$ agarose gel electrophoresis (in TBE buffer $1 \mathrm{x}$ ) and observed by using UVTrans illuminator. The amplified DNA was visualized using UV-Trans illuminator and the success of PCR was detected in the presence of a single DNA band of $700 \mathrm{bp}$ (Fig. 2). It revealed that desired COI of mt DNA was properly polymerized.

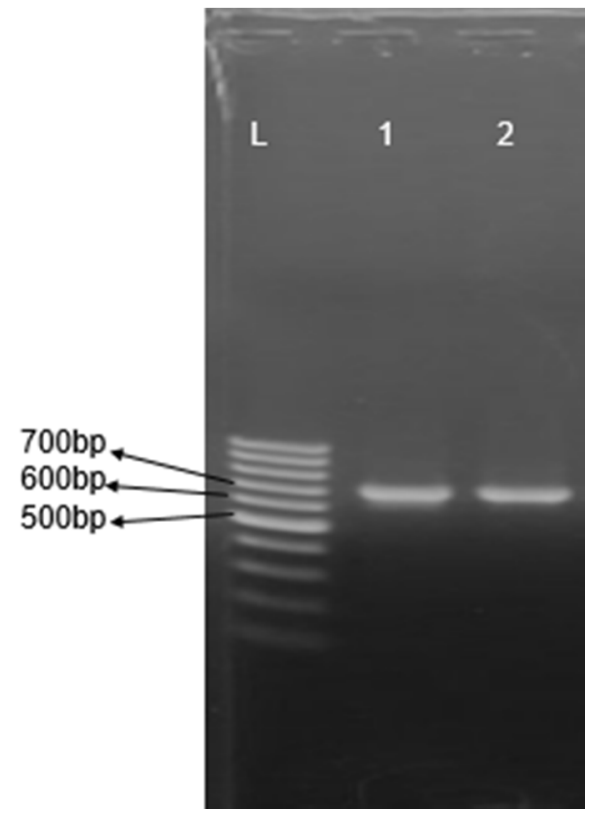

Fig. 2. Agarose gel electrophoresis of mitochondrial DNA cytochrome oxidase $\mathrm{I}(C O I)$ from $C$. transversalis $(1,2), \mathrm{L}=100 \mathrm{bp}$ ladder. 
Coccinella transversalis was sequenced to further confirmation. The PCR product of the mitochondrial cytochrome oxidase subunit I (COI) gene of Coccinella transversalis yielded a single product of $638 \mathrm{bp}$. National Center for Biotechnology Information (NCBI) BLAST was used to check homology between the retrieved sequences and GenBank library or database of sequences. This helped to identify sequence similarity across genomes.

BLAST analysis revealed that the observed sequence no.1 showed 100\% homology with the sequences in GenBank submitted from India, Pakistan, Thailand, Australia and Polynesia (Table 3). It indicates that the observed sample was Coccinella transversalis.

Table 3. BLAST analysis of C. transversalis

\begin{tabular}{lcccccc}
\hline $\begin{array}{l}\text { Species } \\
\text { name }\end{array}$ & $\begin{array}{l}\text { Max. } \\
\text { score }\end{array}$ & $\begin{array}{l}\text { Total } \\
\text { score }\end{array}$ & $\begin{array}{c}\text { Query } \\
\text { cover (\%) }\end{array}$ & E. value & $\begin{array}{c}\text { Identity } \\
(\%)\end{array}$ & $\begin{array}{c}\text { GenBank } \\
\text { Acc. No. }\end{array}$ \\
\hline C. transversalis & 1142 & 1142 & 96 & 0.0 & 100 & MF 140496.1 \\
C. transversalis & 1173 & 1173 & 100 & 0.0 & 99.84 & KY838208.1 \\
C. transversalis & 1168 & 1168 & 100 & 0.0 & 99.69 & MH187251.1 \\
C. transversalis & 1123 & 1123 & 100 & 0.0 & 98.43 & KX052276.1 \\
\hline
\end{tabular}

The sequence was found to be a novel and has been deposited in the NCBI GenBank (Accession No. MG 587949.1).

Nucleotide composition of C. transversalis: Retrieved sequence was subjected for analysis of nucleotide composition (Table 4). Codon positions included were $1 s t+2$ nd $+3 r d+$ non-coding. All positions containing gaps and missing data were eliminated from the dataset. The A, T, G, C, AT and GC content of all sequences was obtained using a computer program (MEGA v.10.0). From the analysis it was found that the average largest number of nucleotide was thiamine (T) and composed of 38.7\% nucleotide and lowest was guanine (G) which composed of $14.6 \%$. The maximum value of adenine and thiamine $(\mathrm{A}+\mathrm{T}$, 69.3) and the minimum value of guanine and cytosine $(G+C, 30.7)$ was also found in C. transversalis. As expected, AT content was found significantly higher than the GC content. It showed similarity with that reported by Aslam et al. 2019.

Table 4. Nucleotide composition of $C$. transversalis

\begin{tabular}{llllllll}
\hline Species & $\mathrm{T}(\mathrm{U})$ & $\mathrm{C}$ & $\mathrm{A}$ & $\mathrm{G}$ & Total & $\mathrm{A}+\mathrm{T}$ & $\mathrm{G}+\mathrm{C}$ \\
\hline C. transversalis & 38.7 & 16.1 & 30.6 & 14.6 & 638.0 & 69.3 & 30.7 \\
\hline
\end{tabular}

Multiple sequence alignment: Sequences were aligned using the MEGA v.10.0. Residue and pairwise distances were estimated using the Clustal W tool with 
default settings of gap opening penalty 15, and a gap-extension 6.6 in pairwise alignment and 0.05 in multiple alignments. Multiple sequence alignment of six $C O I$ gene nucleotide sequences of $C$. transversalis was given in Fig. 3. A total of five sequences from different parts of the world available in the NCBI GenBank were used for a proper comparison. Non-conserved regions were presented by letter and identical or conserved regions were indicated by dot.

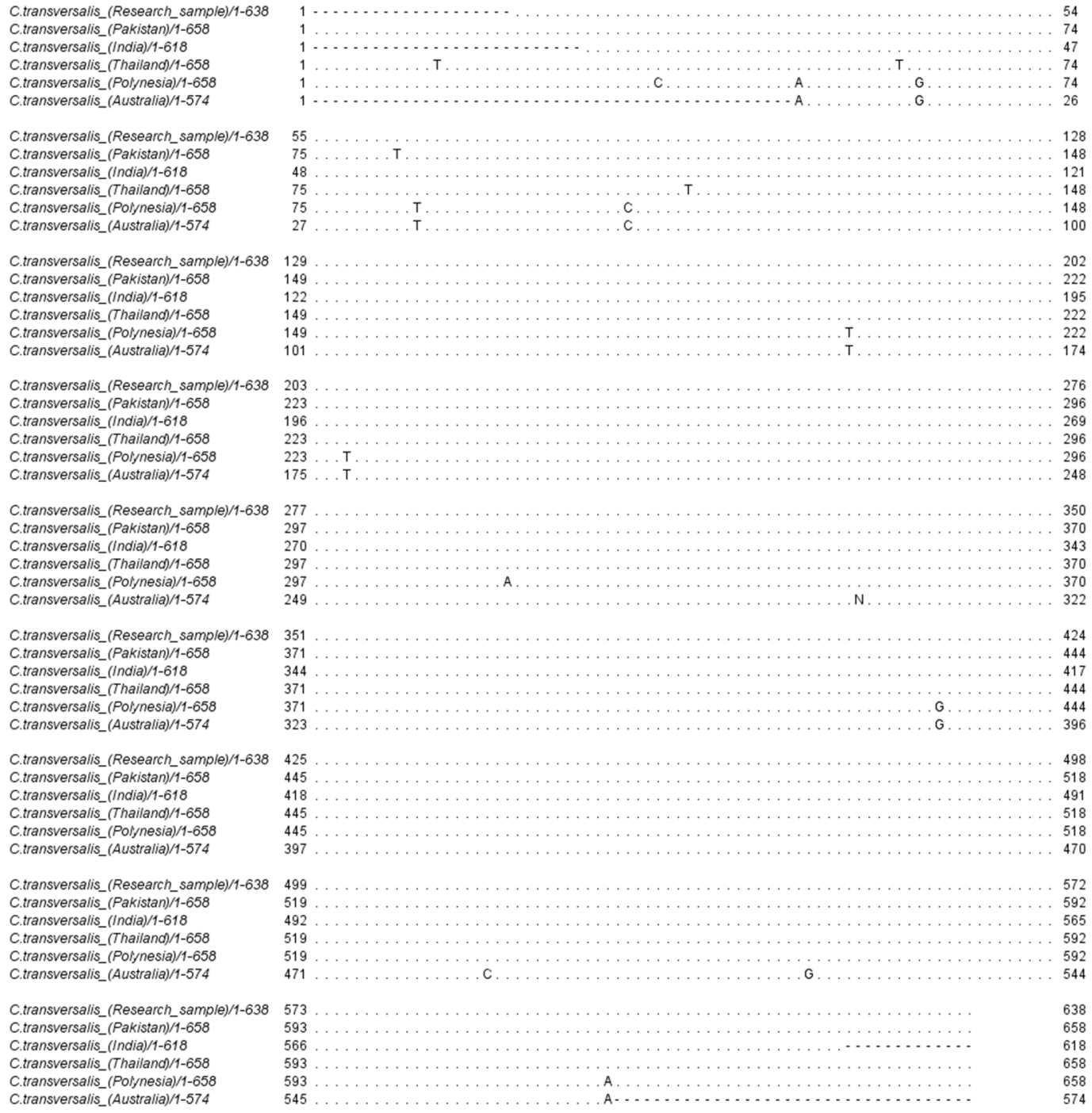

Fig. 3. Multiple sequence alignment based on COI gene sequences of $C$. transversalis. Letter denotes the conserved region and dot means non conserved portion among the four nucleotide sequences. 
Phylogenetic analysis: Maximum likelihood (ML) tree was analyzed to find the phylogenetic relationship among the samples of $C$. transversalis using MEGA v.10.0 software. According to maximum likelihood with $1000 \mathrm{x}$ bootstrap repetition, a phylogeny was constructed (Fig. 4) by the MEGA v.10.0 software using analyzed six sequences (marked as Research sample) of $C$. transversalis. A total of nine sequences from different parts of the world available in the NCBI GenBank were used for a proper comparison. Here, Apis cerana, a bee belongs to the order Hymenoptera was used as an out group. All C. transversalis originated from one clade and showed $100 \%$ genetic diversity among them. The bar at the bottom provides a scale for the genetic change. In this case, the line segment with the number '0.05' showed the length of branch that signifies an amount genetic change of 0.050 .

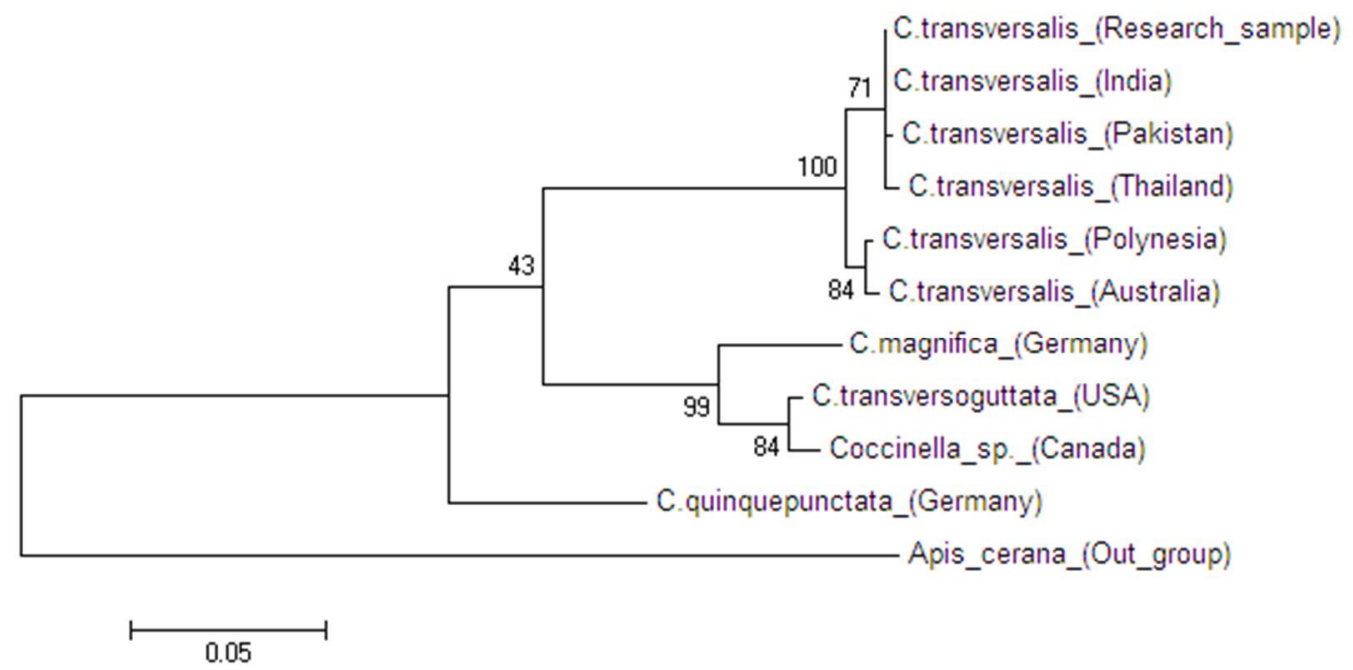

Fig. 4. Molecular phylogenetic analysis by maximum likelihood method. The evolutionary history was inferred using the maximum likelihood method based on the Tamura-Nei model. The tree is drawn to scale, with branch lengths measured in the number of substitutions per site. The percentage of trees in which the associated taxa clustered together is shown above the branches.

Over the last decade the field of DNA barcoding has emerged as a molecular method for species identification. The goal of DNA barcoding is to create a library of every organism on earth (Stoeckle et al. 2004, Kerr et al. 2007). Although the major insect pests in food and their biological control agents are widespread worldwide, only a few studies have been conducted on the DNA barcodes for these species (Seo et al. 2013). Therefore, this study is the first attempt of construction of a DNA reference dataset using the mitochondrial COI gene along with molecular characterization and other related bioinformatics analysis from Bangladesh. Though there are sequences of $C$. transversalis in 
NCBI GenBank, any published paper on molecular characterization of this important biological control agent was not available. This dataset can be effectively used to identify this biological control agent. DNA barcoding can help in identifying such agents in any stage of life. Such identification would help to use this predator as a biological control agent more effectively in nature. Thus, this system would help farmers to save cost of billion dollars from pest damage (Kaur 2015, Sarvananda 2018). Moreover, our results showed the potential role of C. transversalis in bio control of three detrimental agricultural aphids. However, further field based studies are needed to confirm this hypothesis.

Acknowledgements: This work was partially supported by grants from Higher Education Quality Enhancement Project (CP-3424), a project of University Grants Commission of Bangladesh and Ministry of Education, Bangladesh.

\section{LITERATURE CITED}

ABATE, T., VAN, H.A. and AMPOFO, J.K. 2000. Pest management strategies in traditional agriculture: An African perspective. J. Ann. Rev. Entomol. 45: 631-659.

AHMED, M. and AKHTER, S. 2013. Development of insecticide resistance in field populations of Brevicoryne brassicae (Hemiptera: Aphididae) in Pakistan. J. Econ. Entomol. 106 (2): 954-958.

AMPOFO, J.K. and MASSOMO, S.M. 2009. Some cultural strategies for management of bean stem maggots (Diptera: Agromyzidae) on beans in Tanzania. Afr. Crop Sci. J. DOI: tspace.library. utoronto.ca/handle/1807/20304.

ASLAM, A.F.M., SUlTANA, S., RAIN, F.F., SARKER, S., DAS, S.R. and HOWLADER, A.J. 2019. Molecular characterization and identification of three stored grain pests based on mitochondrial cytochrome c oxidase subunit I (COI) gene sequences. Bangladesh J. Zool. 47(1):1-11.

ASLAM, A.F.M. and BASHAR, M.A. 2001. Aphid pest problems on duckweed in minipond ecosystems. Bangladesh J. Zool. 29(2): 159-166.

BALL, S.L. and ARMSTRONG, K.F. 2006. DNA barcodes for insect pest identification. Canadian J. Forest Res. 36(2): 337-350.

BANKS, J.E. and STARKS, J.D. 2011. Effects of a nicotinic insecticide, insidacloprid and vegetarian diversity on movement of a common predator, Coccinella septempunctata. Bioseptic.Int. 7(2): 113-122.

BELLOWS, T.S. 2001. Restoring population balance through natural enemy introductions. Bio. Con. 21: $199-205$.

CHAKRABORTY, D. and KORAT, D.M. 2014. Biology, mormphometry and feeding potential of Coccinella transversalis (Fabricus) on aphids. Indian J. Entomol.77: 197-198.

CHOWDHURY, S.P., AHAD, M.A., AMIN, M.R. and RASEL, N.A. 2008. Bean aphid predation efficiency of lady bird beetle Micraspis discolor F. (Coleoptera: Coccinellidae). J. Soil Nature 2(3): 40-45.

DEAN, D.A. and STERLING, W.L. 1992. A comparison of sampling methods to predict phenology of predaceous arthropods in a cotton agro-ecosystems. J. Agri. Res. 46(8): 257-282.

DIFOnZO, C.D., RAGSDAle, D.W., RADClifFE, E.B., GUMESTAD, N.C. and SECOR, G.A. 1997. Seasonal abundance of aphid vectors of potato virus $\mathrm{Y}$ in the Red River Valley of Minnesota and North Dakota. J. Econ. Entomol. 90: 824-831. 
GARIEPY, D.T., KULHMANN, U., GILLOTT, C. and ERLANDSON, M. 2007. Parasitoids, Predators and PCR: the use of diagnostic molecular marker in control of Arthropods. J. Appl. Ecol. 131(4): 225-240.

GURUNG, B. PONNUSAMY, N. and PAL. S.2018. Biology and feeding potential of lady beetle Coccinella transversalis (Fabricus) (Coleoptera: Coccinellidae) on Lipaphis erysimi (Koch). J. Insect Sci. 31(1-2): 47-50.

HOSSAIN, A.F., FERDOUS, J. and SALIM, M.M.R. 2006. Relative abundance and yield loss assessment of lentil aphid Aphis craccivora Koch in relation to different sowing dates. J. Ari. Rural Dev. 4(1\&2): 101-106.

HEBERT, P.D.N., STOECKLE, M.Y., ZEMLAK, T.S. and FRANCIS, C.M. 2004. Identification of birds through DNA barcodes. Proc. R. Soc. Land. B. Biol. Sci. 2: 1657-1663.

KARPACHEVA, N.S.1991. Ladybird beetle, Zaschchita rastenii. J. Econ. Entomol. 10: 34-35.

KAUR, S. 2015. DNA barcoding and its applications. Int. J. Eng. Res. Gen. 3(2): 602-604.

KENNEDY, J.S., DAY, M.F. and EASTOP, V.F. 1962. A Conspectus of Aphids as Vectors of Plant Viruses. Commonwealth Institute of Entomology, London.

KERR, K.C.R., STOECKLE, M.Y., DOVE, C.J., WEIGT, L.A., FRANCES, C.M. and HEBERT, P.D.N. 2007. Comprehensive DNA barcode coverage of North American birds. Mol. Ecol. Notes. 7: 535-543.

KHURSHEED, R., HUSSAIN, B., AHMED, S.B. and ASHRAF, M. 2006. Biology and feeding potential of Coccenella septempunctata on mustard aphid, Lipaphis erysimi. Int. J. Zool. Res. 2(1): 30-33.

LEVENBOOK, L and WILLIAMS, C.M. 1956. Mitochondria in the flight muscles of insects. J. Gen. Physiol. 39(4): 497-512.

LOHAR, M.K., KHUHRO, S.N., LAKHO, M.H., MAGSI, G.A. and KHUHRO, T.A. 2012. Biology and feeding potential of predator, Hipppdamia convergence Guir (Coleoptera : Coccinella) on mustard aphid, Lipaphis erysimi Kalt.) in laboratory. Pak. J. Agri., Agril. Engg. Vet. Sci. 28(2): 150-159.

LYLA, K. R. and HASEENA, B. 2008. Biology and feeding preference of the coccinellid predator, Coccinella transversalis Fab. Ins. Environ. 14(2): 75-76.

NUNEZ, P.E., TIZADO, E.J. and NIETO, J.M. 1992. Coccinellid (Coleoptera: Coccinellidae) predators of aphids on cultivated plants in Leon. Bole. Sani. Veg. Plagas. 18: 765-775.

GUICKE, D.L., ALEX SMITH, M., JANZEN, D.H., HALLWACHS, W., FERNANDEZ-TRIANA, J., LAURENNE, N.M., ZALDIVAR-RIVERON, A., SHAW, M.R., BROAD, G.R. and KLOPFSTEIN, S. 2012. Utility of the DNA barcoding gene fragment for parasitic wasp phylogeny (Hymenoptera: Ichneumonoidea): Data release and new measure of taxonomic congruence. Mol. Ecol. Resour. 12: $676-685$.

RABOUDI, F., BENMOUSSA, A., MAKNI, H., MARRAAKACHI, M. and MAKNI, M. 2002.Serological detection of plant viruses and host plant in Tunisia. EPP. Bulle. 32: 495-498.

RUGMAN-JONES, P. F., ROBERT, W., TOM, van NOORT.and RICHARD, S. 2009. Molecular differentiation of the Psyttalia concolor (Szépligeti) species complex (Hymenoptera: Braconidae) associated with olive fly, Bactro ceraoleae (Rossi) (Diptera: Tephritidae), in Africa. J. Biol. Control. 49(1): 17-26.

SARVANANDA, L. 2018. Short introduction of DNA barcoding. Int. J. Res. 5(4): 673-685.

SEO, Y.C., KYONG, S. and BAE, Y. J. 2013. DNA barcode library and its efficacy for identifying foodassociated insect pests in Korea. Entomol. Res. 43: 253-261. 
SETHUSA, M.T., MILLAR, I.M., YESSOUFOU, K., JACOBS, A., VAN DER BANK, M. and VAN DER BANK, H. 2014. DNA barcode efficacy for the identification of economically important scale insects (Hemiptera: Coccoidea) in South Africa. African J. Zool. 22(1): 257-267.

SHUKLA, A. and JADHAV, D.S. 2014. Biology of Coccinella transversalis (Fabricus) on different aphid species. J. Bio. 9(1): 17-22.

SINGH, B.B.and SINGH, R. 2014. Major rice insect pests in north eastern UP. Int. J. Life Sc. Bt \& Pharm. 3(1): 124-143.

SOLANGI, B.K., LANJAR, A.G. and LOHAR, M.K. 2007.Biology of 11-spotted beetle Coccinella undecimpunctataL. (Coccinellidae: Coleoptera) on mustard aphid Lipaphis erysimi Kalt. J. Appl. Sci. 7(20): 3086-3090.

STOECKLE, M., WAGGONER, P.E. and AUSUBEL, J.S. 2004. Barcoding Life: Ten Reasons. Consortium for the Barcode of Life, v3.0.Retrieved.from:http://www.barcodeoflife.org/ content/barcoding-life-ten-reasons-pamphlet.

TAMURA, K., PETERSON, D., PETERSON, N., STECHER, G., NEI, M. and KUMAR, S. 2013. MEGA6: Molecular evolutionary genetics analysis using maximum likelihood, evolutionary distance, and maximum parsimony methods. Mol. Biol. Evol. 28: 2731-2739.

(Manuscript received on 10 July, 2019; revised on 10 October, 2019) 